\title{
EXAMINING ORGANIZATIONAL COMMUNICATION ON A NON-GOVERNMENTAL ORGANIZATION: RESEARCH IN CIVIL AVIATION SECURITY OFFICERS ASSOCIATION
}

\author{
DOI: 10.17261/Pressacademia.2021.1451 \\ RJBM- V.8-ISS.3-2021(4)-p.198-205
}

Harun Yilmaz ${ }^{1}$, Savas S. Ates ${ }^{2}$

${ }^{1}$ Iskenderun Technical University, Aviation Management, Hatay, Turkey harun.yilmaz@iste.edu.tr, ORCID: 0000-0002-8467-9019

${ }^{2}$ Eskisehir Technical University, Aviation Management, Eskisehir, Turkey, ssates@eskisehir.edu.tr, ORCID: 0000-0003-2462-0039

\begin{tabular}{l} 
Date Received: April 11, $2021 \quad$ Date Accepted: July 27, $2021 \quad$ OPEN DaccEss $\quad$ (cc)BY \\
\hline To cite this document \\
Yilmaz, H. Ates, S.S., (2021). Examining organizational communication on a non-governmental organization: research in civil aviation security \\
officers' association. Research Journal of Business and Management (RJBM), 8(3), 198-205. \\
Permanent link to this document: http://doi.org/10.17261/Pressacademia.2021.1451 \\
Copyright: Published by PressAcademia and limited licensed re-use rights only.
\end{tabular}

\section{ABSTRACT}

Purpose- One of the most important issues for the survival of organizations is organizational communication. The situation of organizational communication, which will directly affect the relationship between members and management, in non-governmental organizations has been examined. The main purpose of the research is to determine the communication status of the civil society phenomenon and its carrier, the non-governmental organization. Another aim is to analyze the communication and management approach between the management and the members to find solutions to the problems experienced by NGOs. Within the scope of this purpose, organizational communication perception was measured in one of the NGOs operating in the aviation field.

Methodology- The survey method was used as a data collection tool in the research. Within the scope of the research, the scale was communicated to the members of the association via e-mail, WhatsApp, social media, and SMS. Research questions were sent to the participants in September 20019. The online survey remained open until November 2009. The answers of 357 participants who responded to the research were considered valid and included in the analysis. The scales developed by Yiğit (2004) and Takmaz (2009) were adapted to civil society practices and the data were analyzed with Exploratory Factor Analysis.

Findings- According to the results of the research, it can be said that the NGO fulfills its responsibilities towards its members. It is seen that there is a sufficient and strong relationship and communication between the NGO management and the members. The NGO management seeks the opinions of the members when setting targets and also consults the opinions of the members on the issues to be discussed in the higher boards. This increases the trust in the management by making the members feel valued. The presence of transparent and high-level organizational communication in the relevant NGO also contributed to the formation of cooperation between the members and the management. This positive situation within the NGO will also have a positive impact on the member's professional and family life.

Conclusion- Organizational communication is one of the topics of increasing interest in organizations today. Because organizational communication has benefits for the organization and individuals. These benefits increase the performance of the individual and the productivity of the organization. Transparent communication in the organization will contribute to the establishment of an environment of trust in the organization. The fact that the members take part in the management and their opinions are taken on important issues shows the value given to the members. The ability of NGOs to continue their activities for a long time depends on a high level of organizational communication. SIHAGUVDER demonstrates a transparent, fair, and participatory management approach and uses versatile communication methods within the organization. Thus, by gaining the trust of the members, it was ensured that they could take up positions in the management again.

Keywords: Organization, organizational communication, civil society, non-governmental organization, SIHAGUVDER.

JEL Codes: L30, M10, J50

Acknowledgement- This research was supported by the Civil Aviation Safety Association (SiHAGÜVDER) and Eskisehir Technical University was supported by number of 20ADP193 project

\section{INTRODUCTION}

Non-governmental organizations (NGOs) are part of the democratic structure founded on providing benefits for society. Nongovernmental organizations, which are the driving force of social structure, have become one of the key concepts of social progress. It allows the development of a pluralistic and participatory democracy by overcoming the limitations of the 
representative democracy of NGOs. Within the framework of today's governance model, NGOs are a basic structure that undertakes the dialogue effort of social demands.

Lack of democratic traditions in institutions or strict institutional traditions and climate of advice are among the obstacles to the development of civil society. The most important of the security stakeholders in the aviation industry is human resources. Airport security personnel work in a wide area of responsibility, using high technology with increasing security regulations. It is seen that the human factor is effective based on most of the security problems. Airport security personnel are under constant pressure due to different factors such as confusion of authority, increased security regulations, and wide scope of responsibility. It is necessary to support the competencies, authority, and responsibility areas of the personnel working at the airports.

Turkey's first and only NGO related to civil aviation security was established under the name of Civil Airports Protection and Security Officers Solidarity Association (SiHAGÜVDER) on 03.08.2012, headquartered in Ankara. Members of the association have been working at Civil Airports since 1996 at D.H.M.I. It consists of personnel working under the command of the Security Directorate within the General Directorate. The association aims to contribute to the development and encouragement of Turkish Civil Aviation. For this purpose, it has set the target of education, research and promotion activities on the subject to increase the awareness of civil aviation security and service quality. The association carries out activities such as ensuring the formation of the spirit of unity, solidarity between individuals and institutions, supporting the development of its members in professional social-cultural areas, defending the rights and interests of the members, and providing material and moral support to the members and their family members.

NGOs interact with internal and external stakeholders due to their structure. Internal stakeholder interactions in NGOs are possible through interpersonal communication. Being clear and understandable in the communication of NGO members will also affect the implementation processes and external stakeholder relations. NGO members should be able to communicate with representatives and representatives with the management team in a clear, timely, and efficient manner.

The main purpose of the research is to determine the communication status of the civil society phenomenon and its carrier, the non-governmental organization. In the research, the internal communication processes of the members of NGO samples (SiHAGÜVDER) were evaluated. Scales developed by Yiğit (2004) and Takmaz (2009) were adapted as research data collection methods. Data were analyzed with exploratory factor analysis. The questionnaire was filled by 357 members. As a result of the research, communication and governance status were determined and suggestions were made.

\section{LITERATURE REVIEW}

\subsection{Organizational Communication}

One of the most basic features and needs of human beings is to communicate. Communication, which is a life-long process, refers to both the transfer and understanding of discourse and ideas (Robbins \& Judge, 2012, s. 342). There is an exchange of messages between the source and the target in the compulsory process of mutual transfer of news and information, social life, people living and working together in society (Tutar, 2013, s. 32). Communication is the foundation of successful human interaction, regardless of the medium in which it takes place.

Communication is an indispensable element not only for people but also for organizations, communities, and larger masses. Communication also plays an important role in terms of a consciously coordinated social unit consisting of two or more people, functioning on a relatively continuous basis to achieve a goal or set of goals (Robbins \& Judge, 2012, s. 5). In an increasingly complex work environment, the importance of organizational communication as a driver of success also becomes deeper (Marques, 2010, s. 47). Since organizations cannot survive in places where there is no communication, communication is expressed as the basic life source of an organization and a society (Çelikdemir, 2019, s. 431). Better communication is needed for employees in an organization to know and understand each other well, to perform their duties better, and to solve problems more easily (Seyitoglu, 2015, s. 127).

According to the studies conducted by Marquez (2010) in the field of organizational communication, organizational communication is taken as a sub-discipline (Marques, 2010, s. 49). Organizational communication is critical for job performance and strengthening individual-organization relationships (Walden, 2019, s. 316).

Organizational communication, which is the process of mutually influencing and changing the attitudes and behaviors of two or more individuals through information exchange (Kılıç \& Sayglı, 2019, s. 6) Organizational communication ensures the realization of regular relations and mutual dialogues, mutual understanding, sharing of feelings and thoughts, development of common behaviors, cooperation and mutual trust within the organization (Efeoğlu \& Çetin, 2012, s. 187). It is aimed to have effective communication within the organization. Otherwise, job satisfaction and service quality within the organization will be negatively affected (Çelikdemir, 2019, s. 431). 
All kinds of information and ideas exchange within the organization and between the organization and its environment, a positive atmosphere should be established for all employees (Kılıç \& Saygılı, 2019, s. 7). Thus, in the organization, employees can interact with each other and other organizational members verbally or in writing (Tutar, 2013, s. 274). Organizations today are adopting more participatory management styles, which allows communication to focus more on listening, ownership, teamwork, and participation (Marques, 2010, s. 49).

Effective communication processes lie in the background of every organization that wants to be successful in the long run. The main purpose of organizational communication is to facilitate strategic connections and conversations in an organization (Ergle, 2015, s. 220). In addition, it is also important to ensure that the organization's goals and policies are adopted by all employees by ensuring interaction between employees working in various departments of the organization. Giving the employee a sense of importance and increasing the job satisfaction of the personnel in this context can also be achieved through communication. Thus, the functioning of the organization can be sustained and the organization can achieve its goals successfully (Tutar, 2013, s. 274).

Organizational communication has shown to be a crucial element in the success rate of any organization, whether for-profit or non-profit, business or academic-based (Marques, 2010, s. 56Although there are many important functions of communication within the organization, it can be stated that the functions of communication such as providing information, persuading and influencing, giving orders, and combining with teaching-education are more prominent in general (Çelikdemir, 2019, s. 433). Transparency of organizational communication ensures that stakeholders are included in the determination of necessary information to make the right decisions, that organizations are held accountable for their actions and words, and provides accurate, important, and useful information to the relevant parties (Luo, 2018, s. 141). According to Zaremba's (2006) evaluation, 9 criteria have been determined in a successful organizational communication: the right time, clear, accurate, on-site, reliable, responsibility, conciseness, professionalism, and sincerity (Marques, 2010, s. 48).

Internal communication is shaped as much as it reflects the organizational support perceptions of the employees. The perceived employee-top management communication relationship, the quality of work-related information received from colleagues and formal work-related feedback from senior management, input into the decision-making process, colleague feedback, and messages about support sent by management seem to be closely related to organizational support (Amason, 1997, s. 960) .

Organizational communication is divided into two as formal and informal communications in terms of structure. Formal (formal or formal) communication is communication that operates according to certain patterns within organizational rules and in line with the goals of the organization. It can take place through formal channels such as formal meetings and procedures (Efeoğlu \& Çetin, 2012, s. 187). Informal (formal or informal) communication is communication between employees at different levels of the organization, face-to-face or over the phone (Tutar, 2013, s. 275). Communication can take place through informal channels such as gossip and rumor (Efeoğlu \& Çetin, 2012, s. 187). Apart from these, vertical communication from top to bottom and bottom to top within the organization and the communication established by those at the same level between their routine activities are also called horizontal communication (Tutar, 2013, s. 275). In top-down communication, decisions, orders, and instructions are transmitted from superiors to subordinates, while in bottom-up communication, information and results are transmitted from subordinates to superiors. In horizontal communication, communication takes place between employees at the same level to share information and ensure coordination between different departments (Efeoğlu \& Çetin, 2012, s. 187). In organizational communication, senders and receivers can be any company employee that is horizontally or vertically related. The message can be business-related (communication tasks, reporting status, etc.), company-related (information about processes, career options, etc.), or non-work-related (personal experiences, opinions, etc.) (Ergle, 2015, s. 220). Media for this purpose can be private, video calls, phone calls, instant messaging, emails, text mails, notes, intranet, and others (Ergle, 2015, s. 221).

Apart from other activities, if organizations want to increase employee engagement through communication, they must (Ergle, 2015, s. 222):

\section{- Meeting basic communication needs,}

- Encouraging more face-to-face communication and networking by providing opportunities for employees to work together, and enabling them to get to know each other and socialize in informal areas,

- Creating feedback opportunities by developing a gradual communication process that provides a two-way flow of information between employees and management,

- Establishing an open environment where knowledge is freely shared among organizational members without fear, and meaningful interactions take place regularly,

According to Taylor (2009), there are some conditions for an organization to be successful in the communication environment. The most important of these conditions are listed below (Seyitoglu, 2015, s. 127): 
- Quick decision making,

- A competitive vision,

- A different organizational culture from the competitors,

- Change-sensitive "management approach",

- Enterprise,

- Network-based communication structure in the organization,

Organizational communication has many benefits for both individuals and organizations. The benefits for the individual can be listed as follows. Provides information, persuades and changes behavior and attitudes, provides direction and unification, provides control, increases motivation to organizational goals, provides the satisfaction of social needs by expressing emotions (Tutar, 2013, s. 275). When organizational communication works well, job satisfaction, motivation, and organizational commitment increase. Thus, organizational performance increases by creating positive effects on the behavior of employees (Efeoğlu \& Çetin, 2012, s. 186). When the benefits of good communication in terms of the organization are examined, management functions can also be performed successfully in organizations that have a good communication system (Çelikdemir, 2019, s. 433). A study by Clampitt and Downs (1993) revealed a direct relationship between high-quality communication, productivity, and a reduction in absenteeism (Efeoğlu \& Çetin, 2012, s. 187). It is also important that organizational communication be transparent rather than its existence. Because, in addition to the positive relationship between transparent organizational communication and employee engagement, transparent organizational communication has a role in enriching the work resources of employees (Luo, 2018, s. 139).

\subsection{Nongovernmental Organization}

Civil society is a society where individuals can easily develop relationships and engage in socio-cultural activities without getting permission from the state or public power and without fear of prosecution. Organizations or activities are created through voluntary and consensual relationships (Tutar, 2013, s. 71).

NGOs are legal entities that play important roles in the functioning and continuity of the social order. Talas (2011) defines NGOs as "a common living space created by individuals with their desires". Historically, "Civil society" comes from "société civile" in French (Talas, 2011). NGOs are an important factor in determining and sustaining governments. Tosun (2001) defined NGOs and their roles as one of how the state implements democracy widely and effectively. Approaches to civil society (Talas, 2011) (Tosun, 2001);

- Larry Diamon approach: Civil society is a structure established by citizens' own free will, separate from the state.

- The Ernest Gellner approach: This is a broader understanding. According to this thesis, civil society is a structure that fills the gap between the family or the individual and the state.

- John Keane approach: Civil society is the structure that preserves and transforms its own identities by exerting pressure and control over state institutions through non-state activities of its members.

It is also possible to define the different roles of CSOs at the social and individual levels (Özer, 2008). It is possible to list the roles of NGOs as follows (Özer, 2008) (Uğur, 2013):

- It carries out activities that will turn into social benefit in line with its objectives,

- It enables them to raise awareness of the society in their fields and to create a public opinion,

- They can be an element of pressure in line with the demands of society.

- With their democratic internal functioning, they can bring a democratic attitude and civic mentality to their members.

- They take a functional role in the development of civil society

- In societies where there is alienation, people come together and lead to social solidarity.

- They lead in the structuring of economic relations and organizations,

- They fight poverty,

- They carry out activities related to social security, social assistance, and social activities.

Although NGOs undertake important functions in the functioning of democracy, in practice they face important problems in the civil society-state relationship (Gümüş, 2014). NGOs may also experience various problems arising from the inability to 
fully internalize democracy by both the state and civil society, or from the political culture entrenched in the society (Gümüş, 2014).

Due to their nature, NGOs carry out intensive communication activities not only with the state but also with their internal and external environments in their communication activities (Bozkanat, 2020). Yavuzyılmaz and Akıncı (2017) named the communication activities of NGOs with their internal and external environments as integrated communication in their study. In the examination of the websites of NGOs, "dialogical communication", which deals with civil society, public relations, and the Internet, is one of the subjects researched (Özdemir \& Yamanoğlu, 2010) (Aydın \& Aliyeva, 2019).

NGOs can face many problems today. Producing solutions to these problems experienced by NGOs and therefore their members will positively affect the life cycle of the organization as well as the emergence of quality service in the field of activity. Activities are carried out to solve the problems experienced by NGOs. One of them is the "Civil Voices Meeting" event organized by the Civil Society Development Center (STGM). In this event, the Third Sector Foundation of Turkey (TÜSEV) organized a forum on legal obstacles to non-governmental organizations (NGOs), and the problems experienced were itemized as follows (Sivil Toplum Geliştirme Merkezi, 2021):

- Problems within the organization,

- $\quad$ Address issues,

- Groups prevented from organizing,

- Financial problems,

- $\quad$ Legislative problems,

- Insufficient public-NGO cooperation,

It is possible to list the suggestions regarding NGOs as follows:

- Measures should be taken to increase the participation of NGOs in decision-making processes,

- Restrictive regulations on cooperation with NGOs on issues related to the central government should be removed,

- Relations with NGOs should be regulated in all laws related to the organization and duties of ministries or in the law about each institution and organization,

- Obstacles preventing NGOs from cooperating with local governments should be removed.

\section{DATA AND METHODOLOGY}

The research was conducted to measure the organizational communication perception of NGOs operating in the aviation field. The research scale was adapted from Yiğit (2004) and Takmaz (2009).

The number of NGOs operating in the field of aviation in Turkey, which is within the scope of the research, has been determined as 18 as of the end of 2019. Since each NGO has its specific establishment purpose, it was conducted with members of only one of the NGOs that allowed the research. Turkey's first and only NGO related to civil aviation security was established under the name of Airport Security Officers Association (SiHAGÜVDER) on 03.08.2012, headquartered in Ankara. Members of the association have been working at Civil Airports since 1996 at D.H.M.I. It consists of personnel working under the command of the Security Directorate within the General Directorate. The association aims to contribute to the development and encouragement of Turkish Civil Aviation. For this purpose, it has set the target of education, research and promotion activities on the subject to increase the awareness of civil aviation security and service quality.

Due to the insufficient number of academic studies examining the perception of organizational communication in nongovernmental organizations, this research is exploratory. Exploratory research understands the nature of the problem and its purpose is often to guide further research (Efeoğlu \& Çetin, 2012, s. 189). For this purpose, the survey method was used as a data collection tool.

Within the scope of the research, the scale was sent to 1740 members of the association via e-mail, WhatsApp, social media, and SMS. Research questions were sent to the participants in September 20019. The online survey remained open until November 2009. The answers of 357 participants who responded to the research were considered valid and included in the analysis. 


\section{FINDINGS AND DISCUSSIONS}

Reliability analysis of the scale, which was created by benefiting from the researches of Yiğit (2004) and Takmaz (2009), was Cronbach's Alpha $94.7 \%$ (Table 1). The fact that this is greater than $70 \%$ indicates that the scale statements are a valid and reliable tool, the answers are consistent and the questions are understandable.

Table 1: Reliability Statistics

\begin{tabular}{ccc}
\hline Cronbach's Alpha & $\begin{array}{c}\text { Cronbach's Alpha Based } \\
\text { on Standardized Items }\end{array}$ & N of Items \\
\hline, 947 &, 948 & 14 \\
\hline
\end{tabular}

The appropriateness of the statements in the questionnaire and the answers given to these statements to the factor analysis were tested. As a result of the analysis, the KMO value increased to $92.9 \%$ (Table 2). Since it is accepted that the KMO is greater than $60 \%$, it can be said that the data are suitable for factor analysis. It is seen in the table that the P-value is also significant.

\section{Table 2: KMO and Bartlett's Test}

\begin{tabular}{llr}
\hline Kaiser-Meyer-Olkin Measure of Sampling Adequacy. &, 929 \\
Bartlett's Test of Sphericity & Approx. Chi-Square & 4284,059 \\
& df & 91 \\
& Sig. &, 000 \\
\hline
\end{tabular}

Table 3: Total Variance Explained

\begin{tabular}{|c|c|c|c|c|c|c|c|}
\hline \multirow[b]{2}{*}{ Component } & \multicolumn{3}{|c|}{ Initial Eigenvalues } & \multicolumn{3}{|c|}{ Extraction Sums of Squared } & \multirow[t]{2}{*}{$\begin{array}{l}\text { Rotation Sums of } \\
\text { Squared Loadings }\end{array}$} \\
\hline & Total & $\begin{array}{c}\% \text { of } \\
\text { Variance }\end{array}$ & $\begin{array}{c}\text { Cumulative } \\
\%\end{array}$ & Total & $\begin{array}{c}\% \text { of } \\
\text { Variance }\end{array}$ & $\begin{array}{c}\text { Cumulative } \\
\%\end{array}$ & \\
\hline 1 & 8,399 & 59,994 & 59,994 & 8,399 & 59,994 & 59,994 & 7,473 \\
\hline 2 & 1,230 & 8,788 & 68,782 & 1,230 & 8,788 & 68,782 & 6,453 \\
\hline
\end{tabular}

Extraction Method: Principal Component Analysis.

a. When components are correlated, sums of squared loadings cannot be added to obtain a total variance.

Two factors with eigenvalues greater than 1 were found (Table 3). These 2 factors cover $68.7 \%$ of the total variance. This value must be greater than $50 \%$. For the factor analysis to be valid, the KMO (Kaiser-Meyer-Olkin) test result value should be above $60 \%$ and the Bartlett chi-square test should be statistically significant ( $p \leq 0.05$ ) (Nakip, 2013). Factor loadings above 0.40 were taken into account in the factor matrix tables.

In the first factor (Table 4), there are statements about the organization's fulfillment of its responsibilities towards its members and communication with external stakeholders. These statements show that the members think that the organization is making efforts to treat the members equally, to solve the problems experienced by the members inside and outside the organization, to ensure their professional development, and to provide social assistance and solidarity towards the members. It can also be said that the organization fulfills its responsibilities towards its members. These feelings and thoughts will enable the members to create a high level of trust towards the organization and its managers. In this environment of trust, the members facilitate cooperation, reduce the need to monitor each other's behavior, and unite around the belief that other members will not benefit from them (Robbins \& Judge, 2012, s. 320). Members are confident in the activities/practices of the organization and the words and actions of their managers and believe in the current and possible future attitudes and behaviors of the managers (Tutar, 2013, s. 273). Building trust between managers and employees depends on a variety of positive business situations. Trust encourages risk-taking, facilitates information exchange, groups are more active and productivity increases (Robbins \& Judge, 2012, s. 397).

Table 4: Pattern Matrixa ${ }^{a}$

\begin{tabular}{lr}
\hline & Component \\
& 1 \\
\hline NGO provides escalation of my professional issues to the government &, 914 \\
NGO becomes an institution that I apply to solve my problems with general directorate managers. &, 889 \\
The NGO has an important role in helping my professional group reach its deserved place in the general &, 842 \\
directorate &, 789 \\
NGO provides social solidarity of my colleagues in cases of victimization such as death and injury. &, 764 \\
As I am a member of an NGO, I feel professionally strong in conflicts with other institutions. & \\
\hline
\end{tabular}




\begin{tabular}{lr}
\hline NGO managers treat all my friends equally and do not favor anyone &, 693 \\
NGO is a platform for legislative information on problems that should be related to my profession &, 600 \\
NGO had a role in enabling me to easily access the information and documents necessary to do my job &, 514 \\
NGO becomes an institution that I apply to solve my problems with my local administrators. &, 484 \\
My opinion is sought in the determination of the issues in the NGO board of directors meetings &, 889 \\
I believe that the local representative was successful in conveying my views and problems to the NGO &, 847 \\
board of directors. &, 782 \\
I think local representatives are watching our issues closely and working to resolve them. &, 550 \\
I can participate in the determination of NGO management goals &, \\
I believe that the NGO board of directors reacts to the undisciplined actions of the members.
\end{tabular}

In the second factor (Table 4), it can be mentioned that individual-organization harmony and the organization's management values the members and exhibits a participatory management approach. According to the results here, it is seen that the relationship and communication between the organization and the member are strong and sufficient. The organization seeks the opinions of its members when setting goals. Thus, the opinions of the members are taken on the issues to be discussed in the higher boards. Appropriate solutions can be produced by ensuring the direct or indirect participation of the members in the management. Asking and asking members for their opinions makes them stronger. In addition, the problems experienced by the members appear much more clearly. The organization reacts to the wrong behaviors of its members promptly and prevents both them and the organization from being harmed. All these show that the harmony and communication between the organization and the members are sufficient and strong. Managers need to develop their communication skills according to the structure of the organization and the characteristics of the employees (Efeoğlu \& Çetin, 2012, s. 188). In this context, it can be said that the communication skills of SiHAGÜVDER managers are high.

The participants in the research were asked which communication method they follow the activities of the NGOs most. More than half of the respondents stated that they were aware of the activities of the NGO via Facebook (32.9\%) and SMS (24.2\%), respectively. In addition, word of mouth communication from local NGO representatives (19.2\%) and their friends (13.9\%) are other important communication tools (Table 5). The least preferred communication technique by the responding NGO members is the website and other social media (instegram, twitter etc.) tools.

Tablo 5: Method of Following NGO Activities

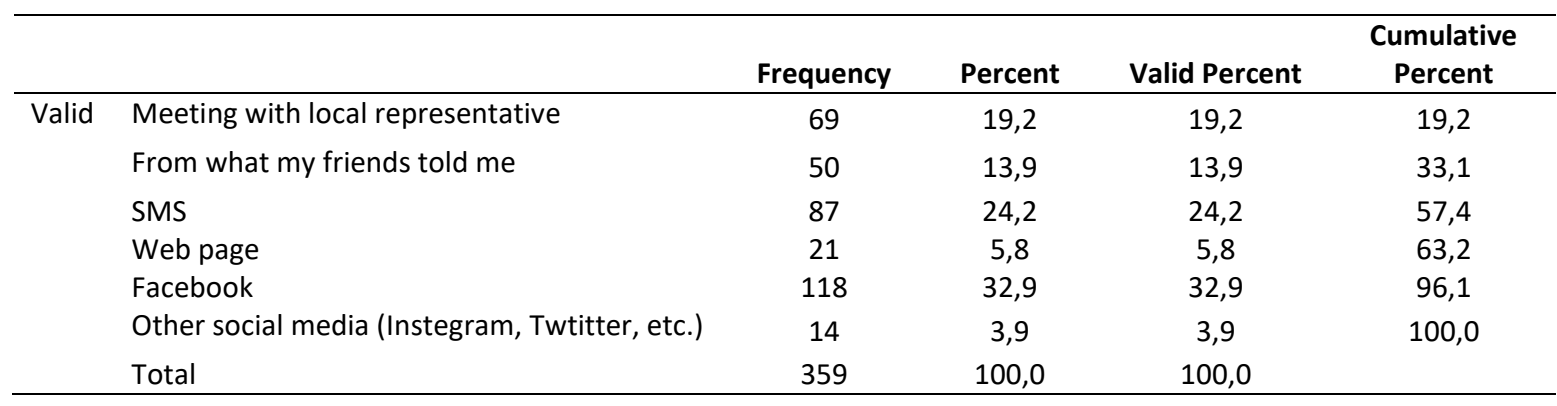

\section{CONCLUSIONS AND IMPLICATIONS}

Continuous and fluent communication in organizations creates trust in managers and contributes to the increase of trust. In a non-governmental organization where organizational communication is at a sufficient level, fast and accurate information flow is provided. In addition, organizational communication shows that non-governmental organization managers are transparent and fair to their members. According to the results obtained by analyzing the data in the study, it can be seen that this situation is implemented within SIHAGÜVDER. It is seen that the members are satisfied with this management approach in SIHAGÜVDER and that the members support the current managers in the elections in the ordinary general assemblies and ensure that they can continue to work. The presence of transparent and high-level organizational communication in the relevant NGO also contributed to the formation of cooperation between the members and the management. This positive situation within the NGO will also have a positive impact on the member's professional and family life. Non-governmental organizations should have an institutional structure, be managed with a professional management approach, and fulfill the promises made by adhering to the predetermined programs.

Meetings with local NGO representatives and word of mouth communication are important in the preferences of getting information about the activities of the NGO. NGO members also follow the activities via SMS. Facebook, one of the social media tools, is preferred more than other tools (instegram, twitter, website, etc.) in following the activities of the NGO. The reason for this is that the age group of NGO members is concentrated in the $36-49$ age range. 
The adoption of the governance approach throughout the organization depends on the communication and cooperation between the members and the management. In the governance process, organization management and local representatives should use communication channels that will enable members to provide feedback. The use of communication tools and accessibility should be at a high level in order for the members to participate in the management, to get their opinions and to have a say in the management. The importance of the continuation of voluntary activities in NGOs should also be emphasized. The development and strengthening of NGOs will contribute to the economic and socio-cultural development of the country.

\section{REFERENCES}

Amason, P. A. (1997). Intra organizational Communication, Perceived Organizational Support, and Gender. Sex Roles, 37, $955-977$.

Aydın, K., \& Aliyeva, M. (2019). Sivil Toplum Kuruluşlarının Web Sitelerinin Diyolojik İletişim Kullanım Düzeylerinin Belirlemeye Yönelik Bir Analiz (Rusya-Türkiye Karşılaştırması). Inönü Üniversitesi Iletişim Fakültesi, 4(2), 168-195.

Bozkanat, E. (2020). Sivil Toplum Kuruluşlarının Sosyal Medyada İlişki Kurma ve İletişim Stratejileri: Yeşilay Türkiye Facebook Sayfası Örneği. Erciyes Iletişim Dergisi, 7(1), 149-168. doi:http://10.17680/erciyesiletisim.595111

Çelikdemir, D. Z. (2019). Örgütsel Değişimin Gerçekleşmesinde Örgütsel İletişimin Önemi. İzmir Iktisat Dergisi, 34(3), $431-441$.

Efeoğlu, İ. E., \& Çetin, S. (2012). Örgütsel Iletşimin Değerlendirilmesi: Belediyelere Dair Uygulamali Bir Çalişma. Ç.Ü. Sosyal Bilimler Enstitüsü Dergisi, 21(3), 185-204.

Ergle, D. (2015). Fostering Employee Engagement Through Gamification: AirBaltic Forecaster Tool. Management, 10(3), 219-234.

Gümüş, A. T. (2014). Dekmokrasilerde Sivil Toplum ve Devlet- Sivil Toplum iliş̧kisinde Karşılaşılabilecek Sorunlar. Gazi Üniversitesi Hukuk Dergisi, 18, 529-572.

Kılıç, T., \& Saygılı, İ. (2019). Örgütsel İletişimin Örgütsel Sessizliğe Etkisinde Örgütsel Bağlılığın Aracı Değişken Rolü: Görgül Bir Araştırma. Uluslararası İtisadi ve Idari Bilimler Dergisi, 5(1), 05-22.

Luo, Y. v. (2018). Crafting employee trust: from authenticity, transparency to engagement. Journal of Communication Management, 22(2), 138-160.

Marques, J. F. (2010). Enhancing the quality of organizational communication A presentation of reflection-based criteria. Journal of Communication Management, 14(1), 47-58

Nakip, M. (2013). Pazarlamada Araştırma Teknikleri. Ankara: Seçkin Yayıncılık.

Özdemir, B. P., \& Yamanoğlu, M. A. (2010). Türkiye'deki Sivil Toplum Kuruluşları Web Sitelerinin Diyalojik İletişim Kapasiteleri Üzerine Bir Inceleme. Ankara Üniversitesi Sosyal Bilimler Enstitüsü Dergisi, 3-36.

Özer, M. H. (2008). Günümüz İtibariyle Sivil Toplum Kuruluşlarının İktisadi ve Sosyal Fonksiyonları. Elektronik Sosyal Bilimler Dergisi, 7(26), 86-97.

Robbins, S. P., \& Judge, T. A. (2012). Örgütsel Davranış Organizational Behavior. (i.. Erdem, Trans.) Ankara: Nobel.

Seyitoglu, F. v. (2015). Organizational Communication in Five Star Hotels and Experienced Problems. International Journal of Science Culture and Sport (IntJSCS), 3(4), 126-139.

Sivil Toplum Geliştirme Merkezi. (2021). Retrieved 06 30, 2021, from https://www.stgm.org.tr/sivil-toplum-kuruluslarinin-sorunlari-ortak

Takmaz, Ş. U. (2009). Illköğretim Okullarında Örgütsel Illetişim Düzeyi ile Öğretmelerin Karara Katılma Davranışları Arasındaki ilişki. Konya: Selçuk Üniversitesi, Sosyal Bilimler Enstitisü, Eğitim Bilimlerin Anabilim dalı, Eğitim Yönetimi Teftişi Planlaması ve Ekonomisi Bilim Dalı Yayınlanmamış Yüksek Lisans Tezi.

Talas, M. (2011). Sivil Toplum Kuruluşları ve Türkiye Perspektifi. Türklük Bilimi Araştırmaları(29), 387-401.

Tosun, G. E. (2001). Demokratikleşme perspektifinden devlet-sivil toplum ilişkisi: Türkiye örneği. İstanbul: Alfa.

Tutar, H. (2013). İşletme \& Yönetim Terimleri Ansiklopedik Sözlük. Ankara: Detay.

Uğur, S. (2013). Sivil Toplum Kuruluşlarının Sosyal Yardım ve Sosyal Sosyal Hizmet Faaliyetleri. Ankara: Ekin Yayınevi.

Walden, J. (2019). Communicating role expectations in a coworking office. Journal of Communication Management, 23(4), 316-330.

Yiğit, ì. (2004). Örgütsel iletişim açısından bilişim teknolojileri ve bir uygulama . İstanbul: Marmara Üniversitesi / Sosyal Bilimler Enstitüsü / İşletme Ana Bilim Dalı / Yönetim ve Organizasyon Bilim Dalı Yayınlanmamış Yüksek Lisans Tezi. 